\title{
ITK Inhibitor
}

National Cancer Institute

\section{Source}

National Cancer Institute. ITK Inhibitor. NCI Thesaurus. Code C156794.

Any agent that inhibits interleukin-2-inducible kinase (ITK). 